\title{
BÁNYAi Éva*
}

\section{„ERDÉLY-RE-PREZENTÁCIÓK” TÖRTÉNETEK AZ ARANYKORRÓL}

\author{
Kulcsszavak: geokulturális narráció, határidentitás, kulturális emlékezet, átmeneti regények
}

A 2000-es évek elejére tehető annak a kortárs magyar prózai - immár bátran nevezhetjük vonulatnak a kezdete, amelynek egyik markáns jegye a múlt század nyolcvanas-kilencvenes évek erdélyi, romániai történelmi/társadalmi fordulatának nyelvi leképezésére/megképzésére tett kísérlet. A totalitárius rendszer és az azt követő átmenet, fordulat elmondhatósága, leírhatósága, narrációvá formálása kiemelt tétje az idesorolható szövegeknek, ezért is neveztem el Fordulat-prózának az általam idetartozónak vélt prózaszövegek együttesét vizsgáló hosszú távú projektemet. Jelen írásom címe: „Erdély-re-prezentációk” az újramondásra és bemutathatóságra tett kísérletek kiemelésére utal, azzal a megkötéssel, hogy úgy vélem: egy „irodalmi régió” nem határolható körül az írók születési- vagy lakhelye alapján, hanem azon szövegek révén határozható meg, amelyek azt nyelvileg megkonstruálják.

A szűk témafelvetés leginkább négy kötetben követhető nyomon: Tompa Andrea: $A$ hóhér háza, ${ }^{1}$ Láng Zsolt: Bestiárium Transylvaniae IV. A föld állatai, ${ }^{2}$ Papp Sándor Zsigmond: Semmi kis életek ${ }^{3}$ és Józsa Márta: Amíg a nagymami megkerül ${ }^{4}$ múveket sorolom első körben vizsgálatom tárgyaként, de tágabb, lazább szálon az átmenetnarratívák sorába tartozik Bartis Attila, Szabó Róbert Csaba, Csender Levente és Vida Gábor több kötete, valamint az általam már korábban elemzett Demény Péter Visszaforgatása ${ }^{5}$ és Dragomán György A fehér királya. ${ }^{6}$

Ami viszont elvont, elvonatkoztatott paradigmaként írja le - kitágítva - a kelet-közép-európai rendszerváltás-történeteket: a Bodor Ádám-trilógia (még akkor is, ha a szerző, de sok értelmezője se tartja a második kötetet az első és harmadik színvonalán). Amennyiben a

BÁNYAI Éva (1971) a Bukaresti Egyetem Hungarológiai Tanszékének docense. Kutatási területe: geokulturalizmus, kultúraköziség, térképzetek és határidentitások a kortárs magyar prózában. Tanított tárgyak: 20-21. századi magyar irodalomtörténet, kortárs magyar próza (alapképzésen), Kultúraköziségi reprezentációk, Térképzetek és határidentitások (mesterképzésen). Megjelent kötetei: Sikertörténet kudarcokkal. Bukaresti életutak, Komp-Press, Kolozsvár, 2006., Térképzetek, névtérképek, batáridentitások, Komp-Press, Kolozsvár, 2011., Aspecte geoculturale in proza maghiară contemporană, Casa Cărții de Știință - RHT, Cluj, 2012., Terek és határok. Térképzetek Bodor Ádám prózájában, Casa Cărții de Știință - RHT Kiadó, Kolozsvár, 2012.

1 Toмpa Andrea: A hóhér háza.Történetek az Aranykorból. Kalligram, Pozsony, 2010. A szövegben megadott lapszámok erre a kiadásra vonatkoznak.

2 LÁNg Zsolt: Bestiárium Transylvaniae IV. A föld állatai. Kalligram, Pozsony, 2011.

3 Papp Sándor Zsigmond: Semmi kis életek. Libri, Budapest, 2011.

4 Józsa Márta: Amíg a nagymami megkerül. Noran, Budapest, 2007.

5 Demény Péter: Visszaforgatás. Koinónia, Kolozsvár, 2006.

6 Dragomán György: A fehér király. Magvető, Budapest, 2005. 
Sinistra körzet ${ }^{7}$ a totalitarizmus elbeszélése, az Érsek látogatása ${ }^{8}$ az átmenet narratívája, a Verhovina madarai $i^{9}$ pedig a túliságot reprezentálja, e három regény mindezt a hatalmi viszonyok teresüléseként tárja elénk. ${ }^{10}$

Az immár több helyen is megjelent, a Fordulat-próza projektembe tartozó szövegeket vizsgáló résztanulmányokban azt igyekeztem kimutatni, hogy miképpen képződik meg a referencialitás és az elvonatkoztatás kettőssége az átmenettörténetekben, hogyan befolyásolják az emlékezet poétikáját a regényekben és a novelláskötetekben megjelenő geokulturális aspektusok, hogyan jelenik meg az Assmann-féle rituális koherenciáról a textuális koherenciára való átmenet, milyen nyelvi-poétikai megformáltságot eredményez az újbóli létrehozás, teremtés, hogyan alakul a múlthoz való viszony, és milyen másság/idegenségtapasztalat, térképzet és határidentitás jelenik meg és formálódik a különböző kultúrák határán, a kultúraköziségben, a köztes térben megképződött prózaszövegben. ${ }^{11}$

Az értelmezések során hangsúlyosan figyeltem a geokulturális aspektusokra, amely tárgyalásánál főként Faragó Kornélia geokulturális elméleteire utalok ${ }^{12}$, ugyanis a fent említett problémahalmazon kívül azt is érdemes megnézni, mennyire meghatározó a szövegértés szempontjából a tárgyak nyelve és a fogalmak nyelve, érthetô-e azoknak (is), akik kívül esnek a geokulturális kötöttségeket egyaránt erősen felvonultató regény szocializációs és térbeli perspektíváján? Ugyanakkor releváns attribútuma az általam kiemelt regényeknek a konkrétumoktól való elvonatkoztatás is: noha ezen regények jó részére kevésbé érvényes a BodorLáng-Dragomán-Papp-Vida-féle viszonylagosító prózapoétikai technika alkalmazása ${ }^{13}$, a meghatározott idősíkokban játszódó és erős topográfiai markerekkel ellátott történetekben a totalitárius rendszerek állandó toposza: a félelem, a mindenkori (hatalmi) kiszolgáltatottság, a bizonytalanság tere is megképződik, és mindezek ábrázolásakor a testpoétika is fontos, kiemelt szerepet kap.

Láng Zsolt regénye, a Bestiárium Transylvaniae IV. A föld állatai egy 17-18 éves szatmári kamaszlány nézőpontjából mutatja be a romániai fordulatot megelőző és követő időszakot. Józsa Márta esszéregénye, az Amíg a nagymami megkerül nem konkrétan az átmenet, fordulat bemutatására törekszik, hanem annak főként előzményeit jegyzi, a hetvenes-nyolcvanas évek Kolozsvárját. Papp Sándor Zsigmond Semmi kis életeiben egy azonosíthatatlan, de határmenti erdélyi város egy társasházának lakóin és azok történetein keresztül elevenednek meg a Ceaușescu-rendszer végnapjai, valamint a fordulat utáni átmenet-lét.

Tompa Andrea könyve, $A$ hóhér háza - Józsa Márta, valamint Demény Péter írásához hasonlóan - Kolozsvár-regény (is), és a Józsa és Láng prózájához hasonlóan szintén egy fiatal

7 Bodor Ádám: Sinistra körzet. Magvető, Budapest, 1992.

8 Bodor Ádám: Az érsek látogatása, Magvető, Budapest, 1999.

9 Bodor Ádám: Verhovina madarai, Magvető, Budapest, 2011.

10 Vö: Bányai Éva: Terek és határok. Térképzetek Bodor Ádám prózájában, Casa Cărţii de Ştiinţă - RHT, Kolozsvár, 2012. 166-167.

11 Lásd pl. BánYai Éva: Fordulat-próza. Térképzetek és átmenet-narrativák a legújabb magyar prózában. = Pieldner Judit - TApodi Zsuzsa (szerk.): A tér értelmezései, az értelmezés terei. Erdélyi Múzeum Egyesület - Státus, Kolozsvár - Csíkszereda, 2012.385-393.

12 FARAGó Kornélia: A viszonosság alakzatai. Forum Könyvkiadó, Újvidék, 2009.

13 Ennek részletes kifejtését lásd: BánYaI Éva: Térképzetek, névtérképek, határidentitások. Komp-Press, Kolozsvár, 2011. 
gyerek/kamaszlány történetein, emlékein, reflexióin, családtörténetén keresztül szerzünk tudomást a diktatúra tobzódásáról és végnapjairól, a rendszerváltás, a fordulat (mert forradalomnak már rég nem szokás nevezni) első napjainak euforikus hangulatáról. A müfajilag is behatárolhatatlan szöveg egyszerre családregény, történelmi regény, korrajz, diktatúratörténet, memoár, fejlődésregény, gyereknarratíva, és - bár az elbeszélő egyes szám harmadik személyben közvetít - énregény is, ugyanis legfóképp egy T. A. monogramú, 71-es karszámot viselő (amely megegyezik a viselője születési évszámával) gyerek-, majd kamaszlány perspektívájából mutatkozik meg - 38 fejezetben ${ }^{14}$ - ez az egyszerre zárt és szövegszerúen kitárulkozó világ.

Az egyes szám harmadik személyú narratíva eltávolító gesztusa is felismerhetô: eltol a szöveg, ugyanakkor beemel bárkit, aki azonosítani akarja/tudja magát a megjelenítettekkel. Ez a grammatikai formula itt az elidegenítés eszköze is: látszólag az író eltávolítja magától a szöveget, noha nagyon is a sajátja az elbeszélt történet, az írásnak erős önmagával való szembenéző erőtere van, de nem tüköreffektus révén (s nem a modorosnak, időnként mesterkéltnek tűnő Józsa Márta-nyelven). A fejezetnyi hosszú mondatok Dragomán regényét idézik, az egy szuszra való megszólalás, mindent elmondani akarás, ugyanakkor a bezártság, de mégis lezárhatatlanság érzetét is, és poétikai relevanciája van az emlékmozaikokból való szövegkonstruálásnak: a töredezett, szaggatott, többoldalas mondatfolyamok a történet elmondhatatlanságának kérdését is problematizálják.

A Tompa-regénynek is - Láng és Józsa prózájához hasonlóan - szövegkonstruáló eleme az elbeszélő gyerek/kamasz nézőpontja, a többszörösen terhelt gender (társadalmi, nyelvi, etnikai, nemi kisebbségi)-perspektíva, amely a saját életfordulópontjából közvetíti a társadalmi-történelmi, nemi-nyelvi fordulatokat.

Jan Assmann $A$ kulturális emlékezet ${ }^{15} \mathrm{c}$. kötetében a rituális koherenciáról a textuális koherenciára való átmenettel kapcsolatos fogalmai Tompa Andrea regényében a textuális felépítésben is tetten érhetők. A regény keretes szerkezetét biztosító történések a kolozsvári rendszerváltás euforikus napjaihoz köthetők: ' 89 decemberével kezdődik a regény a „Tehát elkezdödött" formulával (5.), a kiemelés a szerzőnek tulajdonítható, ezzel is hangsúlyozva az esemény fontosságát. A regény ugyanezen fontos dátum, sors- és rendszerfordító esemény megidézésével zárul, a közbezárt (elég apró betúkkel szedett) háromszáz oldal pedig az egyéni és családtörténeti réteg mellett a romániai-erdélyi-kolozsvári köz- és magándiskurzusainak, a kollektív és a privát emlékezet elmondhatatlannak tűnő, rituális meghatározottságú történeteinek manifesztuma, irodalmi-fikciós konstrukciója. Ez szorosan összefügg a geokulturális narráció jegyeinek érvényesülésével, ugyanis - a többi általam már vizsgált regényhez hasonlóan - Tompa Andrea regénye is olyan nyelvi és nem nyelvi dokumentumok lelőhelye, amelyek azt a kultúrát teresítik, amelyben létrejött, ${ }^{16}$ és akár párhuzamot is vonhatnánk a kortárs román filmmúvészet vitathatatlan nagy kaliberủ alkotásaival, amelyek szintén, akár címükben is, a Tompa-regény alcímét jelenítik meg: Történetek az Aranykorból. ${ }^{17}$

14 Talán annyi éves volt Tompa Andrea, amikor befejezte a regényt.

15 Jan Assmann: A kulturális emlékezet: irás, emlékezés és politikai identitás a korai magaskultúrákban. Atlantisz, Budapest, 1999.

16 Vö.: FARAGó: i. m. 7.

17 Vö.: BALÁzs Imre József: Találkozó történetek. Korunk 2010/10. 111. 
$A$ hóhér háza teljesíti a geokulturális narratológia azon elvárásait is, miszerint a történeti szituáltság kérdései és az átmenetek, határmozgások kiemelései ${ }^{18}$ fontos szövegkonstitúciós eszközök, akár a felmenők tanúsága a megidézett történelmi és térváltások idején, vagy az emigránsok, áttelepülők könyveinek azonosíthatósága (a monogramokról vagy dedikálásokról) a főtéri antikváriumban (6.)

A hóhér házában - Papp Sándor Zsigmond Semmi kis életeihez hasonlóan - nem a narrátor, hanem a megképzett tér a főszereplő, Kolozsvár tere, tér-képe, amely a legtöbb esetben referenciálisan ${ }^{19}$ olvastatja magát (eltekintve attól, hogy a 4-es troli soha nem járt a Mócok útján ${ }^{20}$ ). A tér kiemelkedő szerepét a borító ikonikus, a Fellegvárról fotózott (stilizált) Kolozsvár-képe is erôsíti, amely lehet kiadói stratégia ${ }^{21}$ is, a fülszöveg szintén a geokulturális közeget helyezi előtérbe a totalitárius rendszer járulékos elemének, az „élelmiszerre kidolgozott jegyrendszernek” a megidézésével: „[...] havi fél liter olaj, fél tábla vaj, egy-egy kiló cukor, liszt és máléliszt, 7 darab tojás, valamint csirke és 1 kg-os disznóhúsjegy...”.

A regény térrétegei az elbeszélni vágyott múlt rétegeiből tevődnek egymásra, kiegészülve az időbeli rétegzettséggel, az átmenetek és fordulatok jelzéseivel. Mindez az utcák, terek - a szimbolikus térfoglalás aktusait követő - átnevezéseiben is tetten érhető, ugyanannak az utcának/térnek a szövegbeli mindkét megnevezése szerepel, olykor a helyzet abszurditását is jelezve, pl. „Zápolya (románul Dostoievski)” (38.), de legfóképp a regény címbeli, történelmikulturális múltból eredeztethető, ugyanakkor metaforikus, fikciós terének a lokalizációja is a múlthoz és az emlékezethez való hozzáférés problematikusságát emeli ki. A kolozsvári hóhér háza helyileg az egykori Petőfi utcában volt, amely utca a kulturális és történelmi térváltások lenyomatát is hordozza: „a ház, ahol Petőfi megszállt, már az Avram Iancu utcában állt, azt az utcát pedig, ahol a '48-as forradalmár, kucsmás Iancu lakott, aki Petőfihez képest szép kort élt meg, Petőfi utcának keresztelték, a két utca pedig ironikusan egymás folytatása volt, Petőfi az Avram Iancuban, Iancu pedig a Petőfi Sándorban kapott helyet, mintha ebben a városban végképp senki sem lelne otthonra”. (265.) A tér- és névváltáshoz köthető a regény egyetlen, az időkeretekből és a szövegből kimutató (a megvalósult ,jelenre” vonatkozó) része, amely egy „talánnal” vezetődik be: Petőfi Sándort „talán épp a Dohány utcába rakják majd, és azt keresztelik át, amikor a dohánygyár épülete sem létezik, és senki sem emlékezhet rá, hogy miért nevezték volna éppen Dohány utcának az Alsó-Kereszt utcát, miért ne lehessen akár Petőfi Sándor is". (265-266.)

$\mathrm{Az}$ átmenteket, fordulatokat, térváltásokat bemutató egyik kiemelkedő regényrész a különböző időszakok-beli Hamlet-előadások megidézésével jeleníti meg a 20. század Kolozsvár tér- és történelmi váltásait. „1919. szeptember 30-án, kedden megtartották az utolsó, tünte-

18 Vö.: Faragó: $i . m .8$.

19 Több kritikus is megjegyezte, hogy $A$ hóhér háza kulcsregényként is olvasható. Kiegészítem: legtöbbször kulcs se kell hozzá, mert sok szereplő a teljes nevén szerepel, mint pl. a „nagyfogú, jóságos”, vastag szemüvegú Halmos Kati néni a sajátságos attribútumaival, egy-két költőre viszont valóban csak következtethetünk.

20 Azért is teszem szóvá ezt a szövegből kiemelkedő, a referenciális olvasatból kibillentő „eltérést”, mert a regényegészre nézve nem támasztja alá azt a viszonylagosító prózapoétikai attitűdöt, amely a Bodor-Dragomán-Láng-Papp-Vida-narrációra volt érvényes, lásd BánYAI Éva: Térképzetek, névtérképek, határidentitások. Komp-Press, Kolozsvár, 2011.

21 A könyv eladhatóságára vonatkoztatva. 
tésbe fulladt és végül félbeszakadtként elhíresült Hamlet-előadást a szép, oroszlánokkal díszített Helmer és Fellner tervezte Hunyadi téri Nemzeti Színházban” (112-113.), majd a színészek egy része „repatriál”, más része folytatja a Sétatéri nyári Színkörben, a következő történelmi váltáskor „1941. november 9-én este 7-kor [a Hunyadi téri Nemzeti Színházban] szimbolikusan ugyanannál a Hamlet-sornál folytatják, ahol az 1919-es Hamlet félbeszakadt"(114.) színészváltásokkal, de annál nagyobb lelkesedéssel, hogy 1987-ben, ismét történelmi egérfogóban, és a folyamatos színész-emigrálók miatt is tranzitjellegúvé váló, nevezetes Hamletelőadás a történet folytatását írja elő. Az önmaguk által megképzett csapda foglyai előtt „öszszeömlik a világ”"22, a színházba szerelmes lány a szintén távozni készülő, a mitikussá nőtt Hamlet-előadásban Claudiust játszó színész-zsenin kéri számon az elveit, és a totalitárius rendszer múködését ömleszti össze a hütlen figurával: „ez már nem is Claudius, hanem maga a zsarnok, akibe kapaszkodik, mert elhagyni készül ôt, mert úgy döntött, hogy egyszer csak hátat fordít a szögesdróttal körülkerített börtönnek, amit felépített, magára hagyja keményen átnevelt gyermekeit, fogja magát és kisétál az ajtón, és most már kívülrôl vigyorog »idióta mosollyal«, [...] a börtönné lett Dánia királya kívülrôl figyeli majd, hogy mit kezdenek nélküle a hátramaradók, akik talán közös erôvel újabb zsarnokot jelölnek ki, mert a játékot folytatni kell, mert nem tudnak semmi mást, csak azt, hogy a gyúlölt hóhért, Hamlet apjának gyilkosát nem szabad elengedni”. (116.)

Kolozsvár terének szövegszerú jelenléte erôs testpoétikai vonatkozásokkal érvényesül, egyrészt az ószer tértestének megképzésekor, amely amőbaszerúen terül el a maga meghatározhatatlan körülhatárolhatatlanságában, másrészt $-\mathrm{s}$ ami ennél is fontosabb - A függö város c. fejezetben íródik le: földrengésszerúen megremeg a város a nyolcvanas évek közepén a bontások miatt, a város, a tér a diktatúra erőszakának áldozata lesz, a hóstáti házak, kertek helyére kockablokkokat építenek villámgyorsan, „s a város most,'84-ben, ebben az ijedt várakozásban, mint aki valami nagy-nagy szerencsétlenségre számít, egy végzetes, hirtelen támadó lárvaesőre, ami majd nyomtalanul betemeti, szinte észre sem veszi, hogy szép teste felszíne már berepedezett, az apró, eleinte jelentéktelen seb elgennyesedett, szövetei elfertőződtek, és arcát a betegség kezdi felismerhetetlenül eltorzítani”. (268.)

A konkrét referenciák ellenére vagy azzal együtt is tág és tágítható a szövegben megképzett tér: a totalitárius társadalomszerkezet, a diktatúra bennünk való megformálódása szintjén, a félelem, bizonytalanság, zsarnokság, kiszolgáltatottság, alávetettség, titok, rettegés tereként képződik meg. A totalitárius rendszer ráíródik a testre, képileg is megformálódik a diktatúra arca: $A$ száj című fejezetben gyerektestek formálják meg Ceaușescu s ezáltal a totalitarizmus képét. A stadionbeli (rendszer)alakzatban a gyúlölt diktátor gyerektestek által testesül

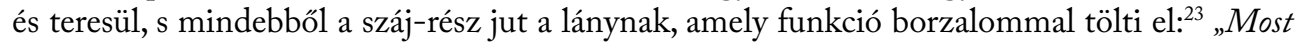
meg az undoritó szája vagyok, jutott hirtelen eszébe, és öklendezve gondolt önmagára meg a ruhára, amit csak nemrég vetett le, úgy érezte, mintha védtelen testét hideg, nyálas ajkak csókolgatnák, fehér, fröcsögő betúket hányna ki rá ez a hatalmas habzó száj, ő maga pedig egy darab élő, undorító, rózsaszín hús lenne kiszakítva, közszemlére hajítva, mert Én vagyok ö,

22 Nem tudom, nyomdahiba-e (sajnos amúgy elég sok van belőle) a világomlást ömlésnek változtató kép.

23 Lásd bővebben: Kovács Flóra: Továbbirás? (Tompa Andrea A hóhér háza cimú kötetéröl. Helikon (Kolozsvár) 2011. július 10.15. [http://www.helikon.ro/index.php?m_r=2603] 
vagy forditva, ó én: a húsa vagyok, elválaszthatatlanul összenőve vele, belém bújt, hogy ne tudjam lemosni sem magamról, a képmását, mint szégyenbélyeget, rám sütötték, én vagyok ő, pontosabban mi mind ő vagyunk, mert együtt, szép fegyelmezett rendbe állítva és vezényszóra fordulva vagyunk ő: hiszen ő maga nem létezik sehol, senki se látta, de nem, Tátá látta és Pista bátyám is, valaha együtt ültek gyúléseken, de most már csak kép, kép, kép, nem ember, hanem kép, amit mi együtt találtunk ki és öntudatlanul rakjuk ki a testünkből” (26. Kiemelés az eredetiben).

A képpé formálódás, a megtestesülés: az öntudatlanul, de mégis részt vevoó és ennek következményeként részt vállaló testekből kirakott diktatúraalakzat rendszermetafora is: mindanynyian formálják a diktatúrát, a testek „kép(e)zik meg”, amely felveti a fikció (emlékezet)teremtő erejét is: a (fiktív) hasonmások létét és a kép(ek) által megkonstruált félelemteret, ahogyan a hóhér házát is az emlékezet építette fel, hogy legyen amitől rettegni. (26.)

Ugyanakkor ,az ember hóhér és a test a háza, amelyben lakik” (152.) - a számtalan hóhér egyike a mindenkori én, amely/aki módszeresen hóhérolja a testét, ennek a regényben - amely, itt jut eszembe, lehetne akár aparegény is - az egyik legeklatánsabb példája, de akár a mitikus, erdélyi nagy, mindent magába temető alkoholizmus megtestesítője az önpusztító apa, aki csak részleges időt nyer a hóstáti kert időtlenségben, ${ }^{24}$ mielőtt a halálba issza magát. Az anya (meg a nagyanya is) számos abortuszon esett át, amelyet értelmezhetünk saját-test(rész)halálként is, de a diktatúra a testet se hagyja ellenőrizetlenül, melynek eredményeként számos „dekrétgyerek" lát napvilágot, és annál is több áldozata lesz a titkos abortuszoknak. A regénybeli nagylánytestvér idetartozó abortusztörténete nemcsak kiegészítő elem, hanem egy fontos regénypoétikai vállalás is: egy soha el nem mesélt történet mondódik el, „de csak így történhetett”(80.), ahogy a narrátor elbeszéli.

Tompánál nem kiemelkedő a szexualitás megjelenítése, főleg a főhőslány saját szexualitásának leírása, leginkább a hajmetaforában testesül meg (a haj, amivel mindig csak gond van), illetve az anyja szexuális életének a kissé ironikus taglalásában, valamint a sokat emlegetett abortuszban. Inkább az eltolás, elhallgatás révén képződik meg a test, illetve a tér testesül mint már jeleztem, Kolozsvár tere -, valamint a hiány (ami sok esetben testhez kötött: meleg víz, fütés, élelem stb.). A hiány, a nemlét olykor erôsebb utalás, mint a látható „valóság”: az újság az elhallgatással közli végérvényesen, hogy nem indul magyar osztály az Ady-Șincai Líceumban (ugyanezzel a módszerrel jelezték a II. világháború idején a zsidótörvények életbe lépését is): „amit nem ír az újság, csak az létezik”(49-50.), és Ceaușescu neve se említődik egy szöveghelyen se, félfülü, főttitkár, főnök, Kárpátok Géniusza, Sinistrul, Odiosul stb.-ként azonosítjuk.

A kulturális heterogenitás alapvető jellemzője Tompa regényének, többszintű és többdimenziós perspektíva révén mutatkozik meg az elbeszélni vágyott világ. A poétikai konstrukció ellenáll az egyneműsítés lehetőségének, különböző, olykor elkülönülő viszonyok és nézőpontok hálózata jön létre. Ezt egyrészt a narráció és a beszédstílusok sokszínűsége, az elbeszélés módozatainak váltakozása biztosítja, másrészt a román nyelvű szövegbetétek, az etnikai, kulturális sokrétegűség, a múlt és szövegjelenbeli elkülönböződés, a másság/idegenség, a határidentitás révén hangsúlyozódik. Ez utóbbi nemcsak a T. A. monogramú, az „elbeszélt tör-

24 Lásd: Szilágyi Zsófia: Tehát elkezdödött. Jelenkor 2011/2. 211-218. http://www.jelenkor.net/ archivum/cikk/2184/tehat-elkezdodott [2013.11.21.] 
ténetư" lány felmenőinek attribútumaira vonatkoztatható, hanem a megnevezés viszonyaiban is tetten érhető: a név nem az állandóság, hanem a permanens transzformáció mutatója, a térelnevezéseken kívül a nagyapa neve is az identitás rögzíthetetlenségét jelzi, ahogyan egy évszázad folyamán Kühn Lászlóból Kun, Kohn, majd Vasile Kohn lesz.

A geokulturális tapasztalat a megértés megkülönböztetésében érezteti hatását: a különféle nyelvi és tárgyi attribútumok használata miatt elkülönülő, helyhez kötött narratívák és értelmezések jönnek létre. Vagyis másként értelmezik azok, akik belül-, és másként, akik kívül vannak a kulturális nyelvhatárokon. ${ }^{25}$ Ezt a regény több kritikusa is szóvá tette, Tompa Andrea is jelezte egy interjúban, hogy számára fontos volt a nem Romániában szocializálódott olvasók szöveghez való hozzáférésének szempontja is, ${ }^{26}$ ugyanakkor fontosnak tartom kiemelni, hogy $A$ hóhér háza olvasható, érthető és értelmezhetó a romániai, totalitárius rendszer relikviáinak, de akár csak a város korabeli történetének az ismerete nélkül is, de a regény egyik releváns rétege, amely a muzealizációra ${ }^{27}$, az összeolvasó stratégiára és a ráismerés poétikájára nyit teret, ez esetben kimarad. A geokulturális teret olyan materiális és immateriális artefaktumok képezik, mint pl. az Alimentarák előtti élelmiszerért való vég nélküli sorbanállás, a cserekereskedelmen és a javak „szerzésén” alapuló társadalmi rend, az iskolai karszám és egyenruha nem viselése (vagy másként viselése, amely a privát szabadság és lázadás latens megnyilvánulása is), az „elvették a villanyt” idióma, amely rendszeralakzat is: a totalitarizmus általi teljes kiszolgáltatottság jele. A „király bohóca”, a városi bolond Lulu, mint minden kolozsvárinak az emlékezetében, a regényben is üdítő színfolt, amely úgy nyeri meg a helyhatósági „választásokat” abban a kifordult világban, az „Aranykorban”, hogy annak nincs is tudatában.

\section{TRANSYLVANIAN RE-PRESENTATIONS}

\section{Keywords: geocultural narrative, border identity, cultural memory, transition novels}

In my study I examine Andrea Tompa's novel entitled "The Hangmen's House" in the light of transition narratives, highlighting the following aspects: How do the geocultural specificities, the border tensions of alterities influence the poetics of memory? How is the transition from ritual coherence to textual coherence represented, how is it textualised? To what extent are the language of objects and the language of concepts determining from the viewpoint of understanding the novel, are they comprehensible also for those who live outside the social and spatial perspective of the novel, heavily relying on geocultural bonds?

25 Egy adott irodalmi szöveget „másként olvassák azok, akik kommunikativ emlékezettel rendelkeznek a szöveg által befogott tér-időről, ezen idő egy részéről legalább, s akiben mindegyik név, fogalom, tárgyforma egy múltbeli, belső világszegmentumot nyit meg, akik saját történetüket, saját egykori kérdéseiket olvashatják bele. És merőben másként értik azok, akik biografikus emlékezet hiányában olvasnak, és újkeletű kérdéseik az olvasás idejében fogannak”. (Kiemelés az eredetiben.) FARAGÓ: $i . m .42$.

26 Balázs Imre József: Hosszúra nyúlt visszatérés. Beszélgetés Tompa Andrea iróval, szinházkritikussal. Helikon (Kolozsvár) 2011. július 10.2. [http://www.helikon.ro/index.php?m_r=2595]

27 Vö.: Faragó: i. m. 16. 


\section{RE-PREZENTAT,II DE TRANSILVANIA}

Cuvinte-cheie: naraţiune geoculturală, identitate liminală, memorie culturală, nuvele de tranziţie

În prezentarea mea analizez concepțiile de spațiu și aspectul de narațiune de tranziție în romanul „A hóhér háza. Történetek az Aranykorból” [Casa călăului. Povestiri din Epoca de Aur] Cum influențează aspectele geoculturale poetica memoriei? Cum apare tranziția de la coerența rituală la coerența textuală, și cum se textualizează? Cât de important e din perspectiva interpretării textului limbajul obiectelor și al noțiunilor, romanul poate fi înțeles și de cei care ies din cercul geocultural, care presupune o perspectivă comună de socializare și spațialitate? 